\title{
Effect of Replacing Corn Silage with Various Forage Silages in the Diet on Carcass Parameters, Meat Quality, Fatty Acid Profile and Amino Acid Composition of Beef Cattle
}

\author{
Xia Zhang, Hu-Cheng Wang ${ }^{*}$ and Mahaboubil-haq Muhaiden \\ State Key Laboratory of Grassland Agro-ecosystems; Key Laboratory of Grassland Livestock Industry Innovation, Ministry \\ of Agriculture and Rural Affairs; College of Pastoral Agriculture Science and Technology, Lanzhou University, Lanzhou, \\ 730000, P. R. China
}

*For correspondence: wanghuch@1zu.edu.cn

Received 16 October 2020; Accepted 05 January 2021; Published 25 March 2021

\begin{abstract}
Carcass parameters, meat quality, fatty acid profile, and amino acid composition of Simmental bulls fed a diet based on various forage silages (VS) compared with the one based on only corn silage (CS) were investigated. A total of thirty male Simmental $(440.5 \pm 11.5 \mathrm{~kg})$ was selected and assigned randomly divided into two treatments. All animals were fed twice daily $(0700$ and $1700 \mathrm{~h})$ and water was supplied ad libitum, feed considering 5 to $10 \%$ refusals. The period of 207 days fattening trial was divided into three stages as P1 (1 to 64 days), P2 (65 to 130 days), P3 (131 to 207 days). Six beef cattle were slaughtered from each group at the end of the experiment. Substituting CS with VS in the finishing diet did not have a significant effect on slaughter performance, nutrient content, fatty acids, and amino acids profile $(P>0.05)$. However, the intramuscular fat and connective tissue content of the VS diet was lower compared with the CS diet $(P<0.05)$. Also, beef cattle fed VS diet could improve eye muscle area, increase histidine content and diameter of muscle fiber. In conclusion, substituting corn silage with various forage silages in the diet of beef cattle could potentially reduce the negative effect under the studied conditions. () 2021 Friends Science Publishers
\end{abstract}

Keywords: Amino acids; Carcass characteristics; Fatty acids; Histological properties; Silage; Total mixed ration

\section{Introduction}

The herbivorous animal husbandry industry is undergoing the initial stage of transformation from "low quality forage + high levels of concentrate" to "high quality forage + low levels of concentrate" mode in China. In the development of modern herbivorous animal husbandry, the focus has been to reduce feed costs, increase economic benefits, expand the use of forage resources, and improve forage storage technology. A variety of forages such as alfalfa, oats, corn and sweet sorghum forage have been widely planted for silage production, bringing forage resource advantages to herbivorous livestock. The high-quality forages instead of concentrate were encouraged in herbivore diets to overcome the shortcomings such as occurrence of metabolic diseases, high feed costs, low nutrient conversion efficiency and poor economic benefits caused by high-level concentrate diets (Schwaiger et al. 2013; Touno et al. 2013; Alstrup et al. 2016; Marques et al. 2016).

The needs of consumers for high-quality and locally raised grass-fed beef have been paid attention to (Marques et al. 2016). Previous studies have recommended beef cattle fed with high-quality forage and a small number of concentrate (Vieira and Fernández 2014) or use local byproducts on the farm (Casasús et al. 2012) to improve the economic benefits of beef production and obtain quality meat.

The carcass and meat quality of ruminants is affected by many factors (Dannenberger et al. 2006), and of these, diet is likely the foremost. The previous studies reported that bulls could adapt to different feeding strategies without significant effect on meat quality (Manni et al. 2018). Also, Alfaia et al. (2009) considered that a high-forage diet had nutritional advantages for ruminants and conducive for the activity of cellulose-decomposing bacteria, which synthesized intermediate isomers, biohydrogenated intermediate isomers trans11-18:1 (t11-18:1) and cis9, trans11-18:2 $(c 9, t 11-18: 2)$ and n-3 polyunsaturated fatty acid (PUFA) of meat.

In this context, considering the importance of the cattle industry and forage utilization needs of good beef as well as the continuous search for efficient and low-cost feed method, we evaluated the effect of replacing corn silage with various forage silage on slaughter performance

To cite this paper: Zhang X, HC Wang, MH Muhaiden (2021). Effect of replacing corn silage with various forage silages in the diet on carcass parameters, meat quality, fatty acid profile and amino acid composition of beef cattle. Intl J Agric Biol 25:895-903 
and beef muscle quality, providing scientific and effective guidance for quality safety, and disease control of beef cattle. We hypothesized that beef cattle fed a TMR with various combinations of silage and concentrate had no negative effects on carcass parameter and beef quality compared with the corn silage on the diet.

\section{Materials and Methods}

This study was performed on basis of the animal care and use protocol approved by the Institute of Ruminants of Lanzhou University (China).

\section{Experimental site}

The experiment was conducted from May 2017 to December 2017 in Dingxi City, Gansu Province, in China. The experimental site $\left(35^{\circ} 07^{\prime} 34^{\prime \prime} \mathrm{N}, 104^{\circ} 59^{\prime} 23^{\prime \prime} \mathrm{E}\right.$, altitude $1899 \mathrm{~m}$ ) belongs to the typical place of the semi-arid and hilly region of the Loess Plateau, with an average annual temperature range of 5.7 to $7.7^{\circ} \mathrm{C}$, frost-free period of 122 to 160 days, with an average annual rainfall range of 300 $\mathrm{mm}$ to $400 \mathrm{~mm}$. The growing season for forage is short, only 120 to 180 days of the year, and droughts are common. More than 3 million acres of artificial forage were planted as alfalfa (Medicago sativa L.), corn (Zea mays L.), oats (Avena fatua L.), and sorghum (Sorghum bicolor L.).

\section{Experimental animals, diets, and design}

The thirty male Simmental $(440.5 \pm 11.5 \mathrm{~kg})$ were selected and randomly divided into two treatments, each group consisting of fifteen animals. A total mixed ration (TMR) with single corn silage + alfalfa hay + concentrate $(\mathrm{CS})$, and TMR with various silage (corn silage + oat silage + alfalfa silage) + wheat straw + concentrate (VS) was used to feed the animals. The fifteen animals in each group were fed in a $100-\mathrm{m}^{2}$ housing unit, each animal was fed in an individual pen, and was allowed access only to its individual ration. All animals were fed twice daily (0700 and $1700 \mathrm{~h}$ ) and water was supplied ad libitum, feed considering 5 to $10 \%$ refusals. The period of 207 days fattening trial was split into three stages as P1 (1 to 64 days), P2 (65 to 130 days), P3 (131 to 207 days), and the formulations were adjusted according to the nutritional requirements of beef cattle at different growth stages using the NRC guidelines (2000). During each fattening phase, the level of concentrates in the diets increased from 52 to $61.75 \%$, and finally to $69.35 \%$ in the CS diet, and from 38 to $42 \%$, and finally to $50 \%$ in the VS diet. Diet composition and nutritional levels are shown in Table 1 and 2.

\section{Slaughter, carcass measurement, and sample collection}

Six bulls from each group were weighed as live BW after $12 \mathrm{~h}$ fast and slaughtered by the Islamic Halal way within
$12 \mathrm{~h}$ at the end of the experiment. The $12^{\text {th }}$ and $13^{\text {th }}$ ribs of the left carcass were selected to measure the eye muscle area (EMA) and backfat thickness (BFT). Longissimus lumborum ( $L L)$ was sampled from the left side of the carcass. Four steaks were collected from each $L L$ sample, one for estimations of meat color and $\mathrm{pH}$, the second piece for measurement of cooking losses and followed by Warner-Bratzler shear force (WBSF) determinations, the third piece for measurement of water loss rate in muscle, and the last piece for analysis of the routine composition, fatty acids, and amino acids. All TMR diets were sampled 4 times a month (once a week) and stored at $-20^{\circ} \mathrm{C}$ until mixed in units of one fattening period. The content of fatty acids and amino acids were determined.

\section{pH value and meat color measurements}

The $\mathrm{pH}$ was determined at $45 \mathrm{~min}, 24 \mathrm{~h}$, and $48 \mathrm{~h}$ postmortem, by inserting a portable $\mathrm{pH}$ meter (Testo 205, TestoAG, Schwarzwald, Germany) probe into the muscle. The meat color $\left(\mathrm{L}^{*}=\right.$ lightness, $\mathrm{a}^{*}=$ redness, $\mathrm{b}^{*}=$ yellowness $)$ was measured using a CM-2600d spectrophotometer (Minolta CR-400, Japan) at 45 min postmortem. Each meat sample was determined three times and the average value was taken as the final value of $\mathrm{pH}$ and meat color.

\section{Warner-Bratzler shear force, water holding capacity measurements}

The WBSF was determined using a meat tenderness tester (RH-N50, Nanjing Xiyi Instrument equipment Co. Ltd, China) following the method (Zhao et al. 2015) at $45 \mathrm{~min}$ postmortem. Briefly, the meat samples were heated in a constant temperature water bath at $85^{\circ} \mathrm{C}$. The samples were taken out and cooled to room temperature after the central temperature reached $70^{\circ} \mathrm{C}$. Then, the steak was cut into six cylindrical cores through a round sampler (diameter $=1.27$ $\mathrm{cm}$ ) for WBSF measurement, the value of WBSF was the average value after six measurements.

For the cooking loss analysis at $45 \mathrm{~min}$ postmortem, $300 \mathrm{~g}$ of muscle was cooked in $85^{\circ} \mathrm{C}$ water bath to a $70^{\circ} \mathrm{C}$ central temperature then the sample was taken out, blotted dry with filter paper, and weighed again. The value of the cooking loss was the percentage of weight change before and after cooking.

At 45 min postmortem, $3 \times 3 \times 1 \mathrm{~cm}$ meat slices were taken from the meat samples and weighed (W1). Then at room temperature, 18 layers of neutral filter paper were put on the top and bottom of the meat sample, and a $35 \mathrm{~kg}$ pressure was applied to the meat sample with a meat quality hydraulic tester (RH-1000, Chongqing Corod Technology Co., Ltd. China). After waiting for $5 \mathrm{~min}$, the meat sample was taken out to weigh again (W2), and calculated according to the following formula:

$$
\text { Water loss rate }(\%)=(\mathrm{W} 1-\mathrm{W} 2) / \mathrm{W} 1 \times 100 \% \text {. }
$$


Table 1: Composition and nutrient levels of experimental diets (DM basis)

\begin{tabular}{|c|c|c|c|c|c|c|}
\hline \multirow[t]{2}{*}{ Ingredients (DM/\%) } & \multicolumn{3}{|c|}{$\mathrm{CS}$} & \multicolumn{3}{|c|}{ VS } \\
\hline & $\mathrm{P} 1$ & $\mathrm{P} 2$ & P3 & P1 & $\mathrm{P} 2$ & P3 \\
\hline Corn silage & 40.00 & 33.50 & 26.80 & 27.00 & 30.00 & 30.00 \\
\hline Oats silage & & & & 15.00 & 14.00 & 10.00 \\
\hline Alfalfa silage & & & & 10.00 & 9.00 & 8.00 \\
\hline Alfalfa hay & 8.00 & 4.75 & 3.85 & & & \\
\hline Wheat straw & & & & 10.00 & 5.00 & 2.00 \\
\hline Corn & 31.00 & 40.10 & 46.95 & 20.00 & 23.00 & 30.00 \\
\hline Bran & 9.00 & 6.00 & 6.00 & 9.00 & 6.00 & 6.00 \\
\hline Soybean meal & 3.00 & 4.30 & 4.30 & 1.00 & 2.00 & 2.00 \\
\hline linseed meal & 5.00 & 6.34 & 7.20 & 5.00 & 6.34 & 7.20 \\
\hline $\mathrm{NaHCO}_{3}$ & 0.80 & 1.09 & 1.00 & 0.80 & 1.09 & 1.00 \\
\hline $\mathrm{CaHPO}_{4}$ & 0.40 & 0.50 & 0.50 & 0.40 & 0.50 & 0.50 \\
\hline $\mathrm{NaCl}$ & 0.20 & 0.30 & 0.30 & 0.20 & 0.30 & 0.30 \\
\hline Premix ${ }^{1)}$ & 2.50 & 3.10 & 3.10 & 2.50 & 3.10 & 3.10 \\
\hline Total & 100.00 & 100.00 & 100.00 & 100.00 & 100.00 & 100.00 \\
\hline Nutrient level & & & & & & \\
\hline ME (MJ/kg) & 13.34 & 14.07 & 14.46 & 13.32 & 14.07 & 14.45 \\
\hline $\mathrm{CP}(\%)$ & 12.89 & 13.18 & 13.80 & 12.86 & 13.16 & 13.78 \\
\hline $\mathrm{Ca}(\%)$ & 0.40 & 0.36 & 0.36 & 0.39 & 0.37 & 0.39 \\
\hline $\mathrm{P}(\%)$ & 0.41 & 0.35 & 0.38 & 0.36 & 0.38 & 0.39 \\
\hline Neutral detergent fiber $(\%)$ & 32.77 & 27.62 & 24.08 & 38.90 & 29.30 & 25.45 \\
\hline Acid detergent fiber $(\%)$ & 17.39 & 13.96 & 11.63 & 19.61 & 15.07 & 13.60 \\
\hline
\end{tabular}

Table 2: Fatty acid and amino acid content of experimental finishing diets fed to beef cattle during different fattening phases

\begin{tabular}{lrrrrrr}
\hline Parameter & \multicolumn{2}{c}{ P1 } & \multicolumn{2}{c}{ P2 } & \multicolumn{2}{c}{ P3 } \\
\cline { 2 - 7 } & \multicolumn{1}{c}{ CS } & \multicolumn{1}{c}{ VS } & \multicolumn{1}{c}{ CS } & \multicolumn{1}{c}{ VS } & \multicolumn{1}{c}{ CS } & VS \\
\hline Fatty acid profile & & & & & & \\
(g/kg) FAME ${ }^{1)}$ & & & & & & \\
C16:0 & 158.10 & 175.23 & 147.00 & 162.00 & 182.23 & 177.45 \\
C18:0 & 110.80 & 77.30 & 121.20 & 80.34 & 118.00 & 95.56 \\
C18:1 & 218.60 & 233.90 & 205.00 & 224.12 & 214.11 & 231.00 \\
C18:2 & 528.00 & 522.00 & 524.11 & 516.34 & 509.00 & 518.70 \\
C18:3 & 75.22 & 57.73 & 66.12 & 54.23 & 76.32 & 59.80 \\
Amino acids (mg/g) & & & & & & \\
Lysine & 6.12 & 8.40 & 8.76 & 8.78 & 9.02 & 8.98 \\
Arginine & 5.72 & 9.67 & 10.45 & 10.12 & 10.44 & 10.89 \\
Methionine & 2.12 & 3.02 & 2.27 & 2.34 & 2.67 & 2.56 \\
Threonine & 5.02 & 5.24 & 5.78 & 5.68 & 6.01 & 6.12 \\
Isoleucine & 0.55 & 0.58 & 0.57 & 0.51 & 0.66 & 0.61 \\
Leucine & 1.01 & 0.81 & 0.82 & 0.79 & 1.00 & 0.96 \\
Phenylalanine & 0.35 & 0.52 & 0.49 & 0.51 & 0.65 & 0.76 \\
Aspartic acid & 10.70 & 9.67 & 10.23 & 10.26 & 11.23 & 11.21 \\
Proline & 9.89 & 10.01 & 9.45 & 9.59 & 8.87 & 8.79 \\
Histidine & 2.03 & 2.31 & 2.56 & 2.68 & 2.90 & 2.96 \\
Cystine & 0.72 & 0.58 & 0.45 & 0.54 & 0.67 & 0.78 \\
Valine & 4.27 & 4.34 & 3.98 & 4.06 & 3.86 & 3.69 \\
Serine & 3.12 & 3.04 & 3.67 & 3.36 & 3.78 & 3.56 \\
Glutamate & 11.20 & 11.56 & 11.03 & 11.23 & 10.76 & 10.91 \\
Glycine & 2.13 & 2.02 & 1.89 & 1.87 & 2.04 & 2.45 \\
Alanine & 1.23 & 1.34 & 1.45 & 1.61 & 1.56 & 1.76 \\
Tyrosine & 1.81 & 1.73 & 1.92 & 1.88 & 2.02 & 2.00 \\
\hline CS group: TMR with single corn silage; VS group: TMR with various silages (corn \\
silage, alfalfa silage, and oat silage) & & & & & \\
1) FAME = fatty acid methyl esters & & & & & \\
& & & & & &
\end{tabular}

\section{Nutritional composition of beef muscle}

The muscle fresh samples were brought back to the laboratory for freeze-drying and ground into a powdered form for the test. Protein, intramuscular fat (IMF), and ash contents of meat were analyzed following AOAC (1995) method. The analyses were performed in triplicate.

The fatty acids (FA) were extracted through the fatty acid methyl ester (FAME) synthesis modified version method of O'Fallon et al. (2007). A $0.5 \mathrm{~g}$ desiccated sample was put into a $10 \mathrm{~mL}$ glass tube with a stopper, $6.3 \mathrm{~mL}$ methanol solution $(0.1 \mathrm{~mol} / \mathrm{L})$ and $0.7 \mathrm{~mL} \mathrm{KOH}(10 \mathrm{~mol} / \mathrm{L})$ was added, and subjected to incubation in a water bath for $90 \mathrm{~min}$ at $55^{\circ} \mathrm{C}$, the glass tube was shaken for $5 \mathrm{~s}$ every 20 min. After the water bath, the glass tube was taken out, cooled to room temperature, and then $0.58 \mathrm{~mL} \mathrm{H}_{2} \mathrm{SO}_{4}(12$ $\mathrm{mol} / \mathrm{L}$ ) was added. The glass tube was subjected to $55^{\circ} \mathrm{C}$ for $90 \mathrm{~min}$ and shaken for $5 \mathrm{~s}$ every $20 \mathrm{~min}$. After the second water bath, the glass tube was taken out, cooled to room temperature, then added $3 \mathrm{~mL}$ n-hexane, shaken, and transferred the solution to a centrifuge tube. Finally, centrifuged at $3000 \mathrm{r} / \mathrm{min}$ for $5 \mathrm{~min}$, then filtered the supernatant into a sample bottle by the organic phase filter membrane, and placed at $-20^{\circ} \mathrm{C}$ for $\mathrm{GC}$ detection. The internal standard C19:0 methyl ester (standard no. N-21M, Nu-Chek, USA) was added to $n$-hexane $(1 \mathrm{~g} / \mathrm{L})$ in advance. The 37 FAME Standards (Supelco, USA) and mixture standard of conjugated linoleic acid (CLA) (Sigma-Aldrich Chemie, Germany) were used. The FA analysis was performed by Agilent technologies 6890N gas chromatograph (Thermo Scientific, TRACE, 1300, Milan, Italy). The chromatographic column model is HP-88 (100 m $\times 0.25 \mathrm{~mm} \times 0.20 \mu \mathrm{m}$, Agilent Technologies, USA), compensation gas flow rate: $40.0 \mathrm{~mL} / \mathrm{min}$; flow rate of hydrogen: $35.0 \mathrm{~mL} / \mathrm{min}$; air flow rate: $35.0 \mathrm{~mL} / \mathrm{min}$; detector temperature: $250^{\circ} \mathrm{C}$; inlet temperature: $250^{\circ} \mathrm{C}$; split ratio: 15:1. FA analysis was an automatic sampler and reference fatty acid standard for retention time identification of individual FA.

The amino acids were determined by the hydrochloric acid hydrolysis method. The desiccated sample was weighed at $10 \mathrm{mg}$, and $10 \mathrm{~mL} \mathrm{HCl}(6 \mathrm{~mol} / \mathrm{L})$ was added, then added $0.2 \mathrm{~mL}$ phenol solution, vacuumed and filled with nitrogen, hydrolyzed at $110^{\circ} \mathrm{C}$ for $24 \mathrm{~h}$, and then filtered into $50 \mathrm{~mL}$ volumetric bottle. After vacuum drying, it was washed with a small amount of deionized water. After steaming, $1 \mathrm{~mL} \mathrm{HCl}$ was added $(0.02 \mathrm{~mol} / \mathrm{L})$ and put through a $0.22-\mu \mathrm{m}$ filter membrane. Hitachi 835-50 amino acid automatic analyzer was used (Jiao et al. 2020). The ion-exchange chromatographic column (650-0042, MembraPure, Bodenheim, Germany) was used, where the amino acids were eluted by the natrium buffer system. After reacting with ninhydrin, the derivatives were tested at 570 $\mathrm{nm}$.

\section{Muscle histological properties}

The three pieces muscle $(1 \times 1 \times 1 \mathrm{~cm})$ of each sample was fixed in $4 \%$ formalin and stained using the hematoxylineosin (HE) staining method to make sections (Wang et al. 2009). After the slices were prepared, it was observed with a 
Table 3: Slaughter performance of beef cattle fed TMR with various forage silage ( $n=6$ per group)

\begin{tabular}{lcc}
\hline Parameter & \multicolumn{2}{c}{ Groups } \\
\cline { 2 - 3 } & $723.94 \pm 14.73$ & $730.50 \pm 11.10$ \\
\hline Slaughter BW ${ }^{1)}(\mathrm{kg})$ & $415.18 \pm 8.89$ & $422.50 \pm 6.99$ \\
Carcass weight $(\mathrm{kg})$ & $57.35 \pm 0.69$ & $57.84 \pm 0.32$ \\
Slaughter rate $(\%)$ & $10.53 \pm 0.96$ & $10.55 \pm 1.08$ \\
Backfat thickness $(\mathrm{mm})$ & $137.87 \pm 16.55^{\mathrm{b}}$ & $149.59 \pm 4.10^{\mathrm{a}}$ \\
Eye muscle area $\left(\mathrm{cm}^{2}\right)$ & & \\
CS group: TMR with single corn silage; VS group: TMR with various silages (corn \\
silage, alfalfa silage, and oat silage) \\
${ }^{1)}$ BW: body weight \\
${ }^{\mathrm{a}, \mathrm{b}}$ Means with different superscript letters in the same row differ from each other $(P$ \\
$<0.05)$
\end{tabular}

Table 4: Effects of TMR with various forage silage on meat quality of Longissimus lumborum from fattening beef cattle ( $\mathrm{n}=$ 6 per group)

\begin{tabular}{llrr}
\hline Parameter & & \multicolumn{2}{c}{ Groups } \\
\cline { 3 - 4 } & & \multicolumn{1}{c}{$\mathrm{CS}$} & $\mathrm{VS}$ \\
\hline Meat color & $\mathrm{L}^{*}$ (lightness) & $30.95 \pm 1.62$ & $29.15 \pm 0.73$ \\
& $\mathrm{a}^{*}$ (redness) & $7.54 \pm 1.09$ & $6.50 \pm 0.46$ \\
& $\mathrm{~b}^{*}$ (yellowness) & $9.20 \pm 1.80$ & $7.80 \pm 0.51$ \\
$\mathrm{pH}$ & $0 \mathrm{~h}$ & $6.01 \pm 0.11$ & $5.93 \pm 0.13$ \\
& $24 \mathrm{~h}$ & $5.57 \pm 0.19$ & $5.54 \pm 0.22$ \\
& $48 \mathrm{~h}$ & $5.41 \pm 0.13$ & $5.48 \pm 0.17$ \\
Water loss rate $(\%)$ & $5.09 \pm 0.56$ & $5.89 \pm 0.51$ \\
Cooked meat rate $(\%)$ & $61.94 \pm 0.26$ & $62.83 \pm 0.19$ \\
Shearing force (N) & $58.86 \pm 0.09$ & $58.24 \pm 0.15$ \\
\hline \multicolumn{2}{l}{ CS group: TMR with single corn silage; VS group: TMR with various silages (corn } \\
silage, alfalfa silage, and oat silage) &
\end{tabular}

Table 5: Effect of TMR with various forage silage on the chemical composition of muscle (Longissimus lumborum) from fattening beef cattle ( $\mathrm{n}=6$ per group) (DM basis, \%)

\begin{tabular}{lrr}
\hline Parameter & \multicolumn{2}{c}{ Groups } \\
\cline { 2 - 3 } & \multicolumn{1}{c}{ CS } & \multicolumn{1}{c}{ VS } \\
\hline Protein & $76.84 \pm 0.99$ & $77.13 \pm 0.89$ \\
Intramuscular fat & $7.15 \pm 0.49$ & $6.14 \pm 0.54$ \\
Ash & $4.41 \pm 0.04$ & $4.34 \pm 0.04$ \\
\hline CS group: TMR with single corn silage; VS group: TMR with various silages (corn \\
silage, alfalfa silage, and oat silage)
\end{tabular}

microscope (ScopeIm-age 9.0) at $4 \times 10$ magnification and stored for photos. For the measurement method of muscle fiber diameter, area, and density referenced to Wang et al. (2018). Briefly, three areas were selected randomly from each sample, and not less than 300 roots muscle fibers were observed, 30 roots muscle fibers were randomly measured for muscle fiber diameter and muscle fiber area. ScopeImage 9.0 was used to measure the long and short diameters of muscle fiber cross-sections, both the geometric mean was regarded as the muscle fibers diameter, and the muscle fibers area of the cross-section was directly measured. The number of muscle fibers in each visual field was measured, and a final, converted to the number of roots per square millimeter to serve as the muscle fiber density of the sample.

\section{Statistical analysis}

Statistical analysis was performed by independent sample $t$ test with S.P.S.S. (v. 19.00). The normality test is carried out before the test, and further analysis can be carried out after the normality is satisfied. Each animal was taken as the experimental unit, $P$-value of 0.05 as the significance criterion.

\section{Results}

\section{Slaughter performance of beef cattle}

As expected, the slaughter BW, carcass weight, slaughter rate, and BFT of the Simmental were similar between the two groups (Table 3). The EMA was significantly greater in the VS group $\left(149.59 \mathrm{~cm}^{2}\right)$ compared with the CS group $\left(137.87 \mathrm{~cm}^{2}\right)(P<0.05)$ (Table 3).

\section{Meat quality of beef cattle}

Table 4 showed that neither treatment nor acid drainage time showed significant differences in muscle $\mathrm{pH}$ value. We found that the shear force values were not significantly different between the two groups. The type of diets did not affect the WHC of beef muscle. No difference was observed in the cooking loss of beef between the two groups in the present study. And more, the $\mathrm{L}^{*}$ (lightness), $\mathrm{a}^{*}$ (redness), and $b^{*}$ (yellow) chromaticity of meat were not influenced by diet composition.

Nutrient content, fatty acid profile, amino acid composition of the longissimus lumborum

Nutrient content: There were no significant differences in the protein, IMF, and ash content between the two groups $(P>0.05)$, however, the content of IMF was 6.14 and $7.15 \%$ in the VS group and CS group, respectively (Table 5). Fatty acid profile: The diet treatment did not significantly affect the fatty acid composition of the muscle (Table 6). The main fatty acid included palmitic (C16:0), stearic (C18:0), and octadecenoic (C18:1n9c) acids, which together accounted for $75.27 \%$ of the total fatty acids. The main intermediate products of rumen biohydrogenation were trans-vaccenic acid (C18:1n9t), vaccenic acid $(\mathrm{C} 18: 1 \mathrm{n} 9 \mathrm{c})$, linolelaidic acid (C18:2n6), conjugated linoleic acids (CLA), and linolenic acid (C18:3n3), which accounted for 44.89 and $47.04 \%$ of the total fatty acids in the CS and VS groups respectively. The CLA which have great benefits for human health was 0.25 and $0.32 \%$ in the CS and VS groups respectively. Overall, the saturated fatty acid (SFA) was $47.41 \%$ in the CS vs. $45.44 \%$ in the VS group of the total fatty acids, the monounsaturated fatty acids (MUFA) were $39.40 \%$ in the CS vs. $40.02 \%$ in the VS group, and polyunsaturated fatty acids (PUFA) were $12.94 \%$ in the CS vs. $14.23 \%$ in the VS group. Within PUFA, the $\mathrm{n}-6: \mathrm{n}-3$ PUFA were 3.32 and 3.02 in the CS and VS group, respectively. Likewise, the ratio of $\mathrm{P} / \mathrm{S}$ was 0.27 and 0.31 in the CS and VS group.

Amino acid composition: There were no significant 
Table 6: Effect of TMR with various forage silage on the fatty acid profile (mg/g, DM basis) of muscle (Longissimus lumborum) from fattening beef cattle ( $\mathrm{n}=6$ per group)

\begin{tabular}{|c|c|c|}
\hline \multirow[t]{2}{*}{ Parameter } & \multicolumn{2}{|c|}{ Groups } \\
\hline & $\mathrm{CS}$ & $\mathrm{VS}$ \\
\hline ¿Fatty acids (mg/g) & $100.21 \pm 2.56$ & $92.79 \pm 2.16$ \\
\hline$\overline{\mathrm{C}} 10: 0$ & $0.64 \pm 0.06$ & $0.60 \pm 0.07$ \\
\hline $\mathrm{C} 12: 0$ & $0.59 \pm 0.05$ & $0.48 \pm 0.04$ \\
\hline C14:0 & $2.22 \pm 0.10$ & $1.90 \pm 0.09$ \\
\hline $\mathrm{C} 14: 1$ & $0.27 \pm 0.01$ & $0.29 \pm 0.01$ \\
\hline C15:0 & $0.34 \pm 0.02$ & $0.30 \pm 0.02$ \\
\hline C16:0 & $25.32 \pm 0.15$ & $22.77 \pm 0.17$ \\
\hline $\mathrm{C} 16: 1$ & $3.14 \pm 0.16$ & $2.66 \pm 0.14$ \\
\hline C17:0 & $1.33 \pm 0.10$ & $1.13 \pm 0.11$ \\
\hline $\mathrm{C} 17: 1$ & $0.65 \pm 0.05$ & $0.52 \pm 0.04$ \\
\hline C18:0 & $16.88 \pm 0.16$ & $14.90 \pm 0.18$ \\
\hline $\mathrm{C} 18: \ln 9 \mathrm{t}$ & $1.81 \pm 0.12$ & $1.67 \pm 0.09$ \\
\hline C18:1n9c & $33.42 \pm 0.26$ & $31.99 \pm 0.23$ \\
\hline $\mathrm{C} 18: 2 \mathrm{n} 6 \mathrm{t}$ & $2.37 \pm 0.11$ & $2.11 \pm 0.10$ \\
\hline $\mathrm{C} 18: 2 \mathrm{n} 6 \mathrm{c}$ & $5.85 \pm 0.07$ & $5.64 \pm 0.09$ \\
\hline CLA & $0.45 \pm 0.06$ & $0.30 \pm 0.01$ \\
\hline C18:3n3 & $1.91 \pm 0.06$ & $1.94 \pm 0.08$ \\
\hline C20:0 & $0.09 \pm 0.01$ & $0.08 \pm 0.01$ \\
\hline C20:1 & $0.12 \pm 0.02$ & $0.12 \pm 0.02$ \\
\hline $\mathrm{C} 20: 3 \mathrm{n} 6$ & $0.68 \pm 0.03$ & $0.61 \pm 0.01$ \\
\hline $\mathrm{C} 20: 4 \mathrm{n} 6$ & $1.74 \pm 0.09$ & $1.56 \pm 0.12$ \\
\hline $\mathrm{C} 20: 5 \mathrm{n} 3$ & $0.67 \pm 0.03$ & $0.65 \pm 0.01$ \\
\hline $\mathrm{C} 22: 5 \mathrm{n} 3$ & $0.71 \pm 0.04$ & $0.69 \pm 0.02$ \\
\hline$\sum \mathrm{SFA}$ & $47.41 \pm 1.26$ & $42.16 \pm 1.16$ \\
\hline$\sum$ MUFA & $39.41 \pm 0.76$ & $37.13 \pm 0.87$ \\
\hline $\bar{\Sigma}$ PUFA & $12.94 \pm 0.56$ & $13.20 \pm 0.56$ \\
\hline n-6/n-3PUFA & $3.32 \pm 0.02$ & $3.02 \pm 0.06$ \\
\hline $\mathrm{P} / \mathrm{S}$ & $0.27 \pm 0.04$ & $0.31 \pm 0.03$ \\
\hline \multicolumn{3}{|c|}{$\begin{array}{l}\text { CS group: TMR with single corn silage; VS group: TMR with various silage (corn } \\
\text { silage, alfalfa silage, and oat silage). }\end{array}$} \\
\hline \multicolumn{3}{|c|}{ CLA: cis-9. trans-11 conjugated linoleic acid } \\
\hline \multicolumn{3}{|c|}{ SFA: Saturated fatty acid } \\
\hline \multicolumn{3}{|c|}{ MUFA: Monounsaturated fatty acids } \\
\hline \multicolumn{3}{|c|}{ PUFA: Polyunsaturated fatty acids } \\
\hline P/S: Polyunsaturated fa & aturated fatty acic & \\
\hline
\end{tabular}

differences in the contents of amino acids, which are essential amino acid (EAA), nonessential amino acid (NEAA), delicious amino acid (DAA), and functional amino acid (FAA) between the two groups, except histidine $(\mathrm{P}>0.05)$. The content of histidine in the VS group was significantly higher than that in the CS group $(\mathrm{P}<0.05)$. The content of EAA was 41.54 and $42.62 \%$ in the CS group and VS group respectively. The ratio of EAA/NEAA in the two groups was about 0.91 (Table 7). Also, the content of TAA and the percentage of each amino acid in the VS group were higher than that in the CS group.

\section{Muscle histological properties}

The diameter of muscle fiber was greater for the VS group compared to the CS group ( $\mathrm{P}=0.04)$, and connective tissue content was lower $(\mathrm{P}=0.05)$ (Table 8; Fig. 1).

\section{Discussion}

Carcass weight is an individual trait influenced by factors such as heredity, breeding method, live weight before slaughter, and market time (Petit 2005). The slaughter rate should be more than $55 \%$, and was larger in beef cattle when the BW is more than $600 \mathrm{~kg}$ before slaughter, consistent with the results of this study. Back fat is an important parameter to reflect fat deposition, as a higher back fat was negatively related to the lean meat percentage. Lerch et al. (2015) found that the BFT of beef cattle was greatly affected by breed. In the present study, the experimental animals were Simmental; the BFT had no significant difference between the two groups. Besides, there is a positive correlation between EMA, as a growth index, and meat production performance, and lean meat percentage. In the present study, the EMA in the VS group was higher compared with the CS group; illustrating that TMR with various forage silage might be beneficial for increasing meat yield. It should be related to the VS group increased dry matter intake with an increase in roughage proportion compared with the CS group. Further studies should analyze the relationship between the forage ratio and meat yield.

Neither treatment nor acid drainage time showed significant differences in muscle $\mathrm{pH}$, which was consistent with previous studies (Blanco et al. 2018), only a steady decrease in meat $\mathrm{pH}$ was observed in both groups. The final $\mathrm{pH}$ value (5.41 and 5.48 for CS group and VS group respectively) is range from 5.4 to 5.6 after slaughter $72 \mathrm{~h}$ within the normal range (Judge et al. 1988). In the present study, the shear force value (approximately $58.6 \mathrm{~N}$ ) indicated that the meat not be called tender meat with a shear force value equal to or less than $40 \mathrm{~N}$ (Perry et al. 2001). Meat tenderness is affected by many factors, including diet, age, growth rate, and length of fattening period (Campo et al. 2008). Previous reports indicated that beef tenderness decrease with the length of the fattening time (French et al. 2000). Probably, the animals are fed for a relatively long period to obtain greater slaughter weight, may help explain greater shear force values in the present study.

The water holding capacity (WHC) of meat may be influenced by the rate and extent of $\mathrm{pH}$ descends (Oliveira et al. 2018). In the present study, the type of diets did not affect the WHC of beef muscle, possibly due to a lack of significant differences in the final $\mathrm{pH}$ of the meat. Additionally, there was a negative correlation between WHC and the water loss rate of meat. According to Luciano et al. (2009) and Schafer et al. (2002), the loss of water on the meat could decrease the heme content in the muscle, affecting the superficial color and weight of the meat, and reducing the economic benefit.

The lower the cooking loss, the less loss of protein and fat, and the higher the nutritional value of the muscle (McKenna et al. 2005). No difference was observed in the cooking loss of beef between the two groups in the present study. Similarly, Wales et al. (1998) and Dewhurst et al. (2009) also reported that, little evidence was known as diet composition influenced cooked meat percentage.

The meat color may be affected by diet, especially grass-fed (Priolo et al. 2001). Meat color is not only related 
Table 7: Effect of TMR with various forage silage on the total amino acid profile of muscle (Longissimus lumborum) from fattening beef cattle ( $\mathrm{n}=6$ per group) (DM basis)

\begin{tabular}{lcc}
\hline Parameter & \multicolumn{2}{c}{ Groups } \\
\cline { 2 - 3 } & & VS \\
\hline Essential & $4.41 \pm 0.09$ & $4.54 \pm 0.04$ \\
Threonine (\%) & $4.66 \pm 0.08$ & $4.76 \pm 0.05$ \\
Valine (\%) & $0.84 \pm 0.05$ & $0.78 \pm 0.08$ \\
Methionine (\%) & $3.75 \pm 0.08$ & $3.84 \pm 0.03$ \\
Phenylalanine (\%) & $4.49 \pm 0.09$ & $4.59 \pm 0.04$ \\
Isoleucine (\%) & $7.82 \pm 0.16$ & $8.05 \pm 0.07$ \\
Leucine (\%) & $5.60 \pm 0.12$ & $5.76 \pm 0.05$ \\
Lysine (\%) & $3.88^{\mathrm{b}} \pm 0.05$ & $4.09^{\mathrm{a}} \pm 0.04$ \\
Histidine (\%) & $6.10 \pm 0.12$ & $6.23 \pm 0.07$ \\
Arginine (\%) & & \\
Nonessential & $8.93 \pm 0.17$ & $9.22 \pm 0.09$ \\
Aspartic acid (\%) & $15.99 \pm 0.40$ & $16.40 \pm 0.19$ \\
Serine (\%) & $3.65 \pm 0.07$ & $3.76 \pm 0.04$ \\
Glutamate (\%) & $3.65 \pm 0.07$ & $3.68 \pm 0.06$ \\
Proline (\%) & $4.23 \pm 0.06$ & $4.31 \pm 0.10$ \\
Glycine (\%) & $5.51 \pm 0.09$ & $5.63 \pm 0.05$ \\
Alanine (\%) & $3.00 \pm 0.05$ & $3.09 \pm 0.03$ \\
Tyrosine (\%) & $1.82 \pm 0.03$ & $1.85 \pm 0.01$ \\
Cystine (\%) & $868.10 \pm 16.56$ & $887.11 \pm 9.12$ \\
Total AA (mg/g) & $6.44 \pm 0.13$ & $6.53 \pm 0.12$ \\
Limited Amino Acids (\%) & $41.54 \pm 0.79$ & $42.62 \pm 0.43$ \\
Essential amino acids (\%) & $41.60 \pm 0.83$ & $42.56 \pm 0.50$ \\
Taste amino acids (\%) & $29.91 \pm 0.68$ & $30.67 \pm 0.33$ \\
Functional amino acids (\%) & $0.91 \pm 0.04$ & $0.91 \pm 0.05$ \\
EAA/NEAA & & \\
CS group: TMR with single corn silage; VS group: TMR with various silages (corn \\
silage, alfalfa silage, and oat silage) & & \\
AA: amino acid; & \\
EAA/NEAA: essential amino acid/nonessential amino acid & \\
ab Means with different superscript letters in the same row differ from each other $(P<0.05)$ \\
\end{tabular}

Table 8: Effects of histological characteristics of lion-eye muscle beef cattle fed TMR with forage silage $(n=6$ per group $)(4 \times 10 \mu \mathrm{m})$

\begin{tabular}{|c|c|c|}
\hline \multirow[t]{2}{*}{ Parameter } & \multicolumn{2}{|c|}{ Groups } \\
\hline & $\mathrm{CS}$ & VS \\
\hline Diameter of muscle fiber $(\mu \mathrm{m})$ & $25.24^{\mathrm{b}} \pm 0.56$ & $30.00^{\mathrm{a}} \pm 1.01$ \\
\hline Area of muscle fiber $\left(\mu \mathrm{m}^{2}\right)$ & $557.14 \pm 2.06$ & $812.79 \pm 1.56$ \\
\hline Density of muscle fiber $\left(\mathrm{mm}^{-2}\right)$ & $1109.10 \pm 10.06$ & $1070.43 \pm 9.56$ \\
\hline Connective tissue content (\%) & $41.21^{\mathrm{a}} \pm 0.96$ & $29.23^{\mathrm{b}} \pm 1.16$ \\
\hline
\end{tabular}
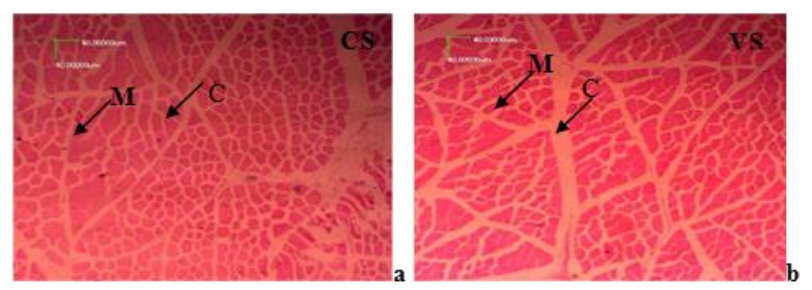

Fig. 1a, b: Histological characteristics of beef muscle CS group: TMR with single corn silage; VS group: TMR with various silages (corn silage, alfalfa silage, and oat silage)

M: Muscle fibers

C: Connective tissue

to intramuscular fat content, muscle $\mathrm{pH}$ value, animal age, and carcass weight (Priolo et al. 2001), but also changes when beef is oxidized by air (Liu et al. 1995). In this study, the $\mathrm{L}^{*}$ (lightness), $\mathrm{a}^{*}$ (redness), and $\mathrm{b}^{*}$ (yellow) chromaticity of meat were not influenced by diet composition. The study results are consistent with previous findings that forage itself had little effect on muscle color (Duckett et al. 2007, 2013). Our findings may also be due to the fact that most factors affecting meat color are not affected by dietary treatment.

Kobayashi et al. (2012) reported that IMF in the muscle was positively related to the level of dietary concentrate level. Similarly, the IMF content was higher in the muscle of cattle fed with concentrate than cattle fed with roughage (Dannenberger et al. 2004). Thus, differences in the ratio of concentrate could lead to differences in the IMF content.

The composition of fatty acid affects the health of meat, and is closely related to the flavor, tenderness, and juiciness of the meat (Fisher et al. 2000). The World Health Organization (WHO) (2003) indicates that the nutritional value of beef is positively correlated with the PUFA ratio, especially the n-3 PUFA ratio. Researchers generally believed that fatty acid composition was significantly affected by diet factors (Enser et al. 1998; Scollan et al. 2001; Dannenberger et al. 2004; Nuernberg et al. 2005). French et al. (2000) found that fatty acid composition in beef could be improved by adding forage in the diet. According to Yu et al. (1995); Wood et al. (2004), compared with concentrate-based feeding method, forage feeding could affect some meat quality indicators, including meat color, flavor, and fatty acid composition. Previous studies' results showed that the n-6: n-3 PUFAs were higher in some high-concentrate diets, while that of livestock mainly fed forage was only about 1.2 (Joy et al. 2014; French 2000). The n-6: n-3 PUFAs ratio of $4: 1$ is recommended by the WHO in a healthy diet (2003). The present study showed that the n-6: n-3 PUFAs of the two groups was $3.32(\mathrm{CS})$ and $3.02(\mathrm{VS})$ respectively, which were close to the recommended value. The WHO (2003) recommended that PUFA/SFA (P/S) should be higher than 0.40 . In this experiment, the ratio of $\mathrm{P} / \mathrm{S}$ (average 0.30 ) was lower than 0.40 , which was still far from the reasonable nutritional recommendation value of 0.40 . As has been also reported the generality of livestock products for the P/S lower than 0.40 , which was necessary to devote ourselves to producing high-quality livestock products in the future.

The amino acid is the basic unit of protein, and important indicators for evaluating the nutritional value of protein, which directly affects the nutritional value of beef (Ludden and Kerley 1998; Gan et al. 2010). The EAA (lysine, threonine, leucine, isoleucine, valine, methionine, tryptophan, phenylalanine, etc.) are the basic indicators for assessing the bioavailability of proteins. They are important nutritional and physiological effects that can only be obtained from outside the body. Histidine and arginine are semi-essential amino acids in the human body, which cannot meet the needs of the human body, and need to be 
taken from food, acting on the regulation of metabolism, dilated blood vessels, cut down blood pressure (O'Connor $e t$ al. 1993; Semba et al. 2016). The DAA includes glycine, glutamate, alanine, and aspartic acid, their content influences the degree of freshness to some extent ( $\mathrm{Li}$ et al. 2001).

The content of histidine in the VS group was significantly higher than that in the CS group, indicating that increase with the content and type of silage forage in the diet could potentially reduce the negative effect. The content of EAA was 41.54 and $42.62 \%$ in the CS group and VS group, respectively, which are close to the ideal amino acid value $(40 \%)$. The ratio of EAA/NEAA in the two groups was about 0.91 , which was greater than the recommended value (approximately 0.6) of FAO (1973), indicated that the two groups diet from this study produces relatively nutritious meat. Thus, the content of amino acid in the VS group was more likely to approach or exceed the corresponding content of amino acid in the ideal protein, which may be beneficial to improve the utilization of protein in the human body, resulting from the overall interaction effect between nutrients in different feeds combinations.

Previous studies had shown that the histological characteristics of muscle fibers determined meat quality and were closely related to food quality traits (Zeng et al. 1999). The muscle fibers could be affected by the nutritional status, breed, age, and athletic ability of the animal. Guo and $\mathrm{Li}$ (2008) showed that muscle fibers were related to the shear force and tenderness of muscle. Also, the muscle fiber diameter of meat products was negatively correlated with muscle fiber density. There was a positive correlation between the diameter of muscle fibers and the slaughter rate and eye muscle area for the same species ( $\mathrm{Li}$ et al. 2017). Zhao and Yang (2003) showed that muscle fiber area increased with an increase of the diet nutrient levels in pigs of the same weight. Also, Swatland (1997) found that the structural distribution and content of connective tissue are related to water loss and muscle succulence. Hence, the results of this study indicate that diets with various silage matchings, a small number of concentrates in beef cattle can improve muscle fiber, and thus meat quality.

\section{Conclusion}

Beef cattle can be fed TMR including corn silage, or a mixture of corn silage, alfalfa silage, and oat silage during the fattening stages with little difference in beef quality. A TMR based on various forage silages can improve eye muscle area of beef cattle, increase histidine content in muscle, and diameter of muscle fiber. Furthermore, connective tissue content of the VS group was lower compared with the CS group. In conclusion, substituting corn silage with various forage silages in the diet for beef cattle could be a feasible strategy to raise fattening beef cattle in the intensive feedlot system.

\section{Acknowledgments}

We thank the support from National Key R\&D Program of China (No. 2017YFE0104300), the Second Tibetan Plateau Scientific Expedition and Research (STEP) program (2019QZKK0302), and Dingxi City Science and Technology Plan (071100032). We gratefully acknowledged Prof. An Jizhong, Mr. Wang Weizhong, Ms. Ma Peilin, and all staff of the Jia Tianxia beef cattle farm in Dingxi City, Gansu Province for their help. We also thank Ali Sher Bacha for guidance on English correction.

\section{Author Contributions}

Hu-Cheng Wang conceptualized the work and provided laboratory facilities for analyzing and financial support; Xia Zhang collected and analyzed the data, and visualized the results; Xia Zhang and Mahaboubil-haq Muhaiden wrote and edited the paper.

\section{Conflict of Interest}

There is no conflict of interest among the authors and institutions where the research has been conducted

\section{Data Availability Declaration}

Primary and supplementary data reported in this article are available with the corresponding authors

\section{Ethics Approval}

This study involving animals was reviewed and approved by the Institutional Animal Care and Use Committee of the author(s). Animals were humanely sacrificed as necessary to ameliorate suffering. Procedures were performed in accordance with the ARRIVE guidelines available at: PLoS Bio 8(6), e1000412,2010 (authors are strongly encouraged to carefully read these guidelines)

\section{References}

Alfaia CPM, SP Alves, SIV Martins, ASH Costa, CMGA Fontes, JPC Lemos, JAM Prates (2009). Effect of the feeding system on intramuscular fatty acids and conjugated linoleic acid isomers of beef cattle, with emphasis on their nutritional value and discriminatory ability. Food Chem 114:939-946

Alstrup L, K Söegaard, MR Weisbjerg (2016). Effects of maturity and harvest season of grass-clover silage and forage-to-concentrate ratio on milk production of dairy cows. J Dairy Sci 99:328-340

AOAC (1995). Official Methods of Analysis, $16^{\text {th }}$ edn. Association Official Analytical Chemists, Arlington, Virginia, USA

Blanco C, R Bodas, L Morán, J Mateo, S Andrés, FJ Giráldez (2018). Effect of hop (Humulus lupulus L.) inclusion in the diet for fattening lambs on animal performance, ruminal characteristics, and meat quality. Food Res Intl 108:42-47

Campo MD, G Brito, JMSD Lima, DV Martins, C Sañudo, RS Julián, F Montossi (2008). Effects of feeding strategies including different proportion of pasture and concentrate, on carcass and meat quality traits in Uruguayan steers. Meat Sci 80:753-760 
Casasús G Ripoll, P Albertí (2012). Use of maize silage in beef heifers fattening diets: Effects on performance, carcass, and meat quality. Inform Technol Econ Agrar 108:191-206

Dannenberger D, K Nuernberg, G Nuernberg, K Ender (2006). Carcass and meat quality of pasture $v s$. concentrate fed German Simmental and German Holstein bulls. Arch Anim Breed 49:309-414

Dannenberger D, G Nuernberg, W Schabbel, H Steinhart, K Ender, K Nuernberg (2004). Effect of diet on the deposition of n-3 fatty acids, conjugated linoleic and C18:1 trans fatty acid isomers in muscle lipids of German Holstein bulls. J Agric Food Chem 52:6607-6615

Dewhurst RJ, L Delaby, A Moloney, T Boland, E Lewis (2009). Nutritive value of forage legumes used for grazing and silage. Irish J Agric Food Res 48:167-187

Duckett SK, JP Neel, RM Lewis, JP Fontenot, WM Clapham (2013). Effects of forage species or concentrate finishing on animal performance, carcass, and meat quality. J Anim Sci 91:1454-1467

Duckett SK, JPS Neel, RNJ Sonon, P Fontenot, WM Clapham, G Scaglia (2007). Effects of winter stocker growth rate and finishing system on: II. Nineteenth-eleventh rib composition, muscle color, and palatability. J Anim Sci 85:2691-2698

Enser M, KG Hallett, B Hewett, GAJ Fursey, JD Wood, G Harrington (1998). Fatty acid content and composition of UK beef and lamb muscle in relation to production system and implications for human nutrition. Meat Sci 49:329-341

FAO (1973). Energy and Protein Requirements. Food and Agriculture Organization of the United Nations and the World Health Organization, FAO Food and Nutrition

Fisher AV, M Enser, RI Richardson, JD Wood, GR Nute, E Kurt, RG Wilkinson (2000). Fatty acid composition and eating quality of lamb types derived from four diverse breed $\times$ production systems. Meat $S c i$ 55:141-147

French P (2000). Fatty acid composition, including conjugated linoleic acid, of intramuscular fat from steers offered grazed grass, grass silage, or concentrate-based diets. J Anim Sci 78:2849-2855

French P, EG O'Riordan, FJ Monahan, PJ Caffrey, M Vidal, MT Mooney, AP Moloney (2000). Meat quality of steers finished on autumn grass, grass silage or concentrate-based diets. Meat Sci 56:173-180

Gan CI, SS Guo, JH Rong, SB Xiong (2010). Analysis of the main nutritional components of crisp meat sole muscle. J Nutr 32:513-515

Guo Y, B Li (2008). Study on physico-chemical properties and meat qualities of different parts of small-tail han sheep carcass. Food Sci 29:143-147

Jiao J, T Wang, J Zhou, AA Degen, N Gou, S Li, Y Bai, X Jing, W Wang, Z Shang (2020). Carcass parameters and meat quality of Tibetan sheep and Small-tailed Han sheep consuming diets of low-protein content and different energy yields. J Anim Physiol Anim Nutr104:1010-1023

Joy M, R Ripoll-Bosch, A Sanz, F Molino, I Blasco, J Álvarez-Rodríguez (2014). Effects of concentrate supplementation on forage intake, metabolic profile and milk fatty acid composition of unselected ewes raising lambs. Anim Feed Sci Technol 187:19-29

Judge MD, ED Aberle, JC Forrest, RA Merkel (1988). Principles of Meat Science. Kendall Hunt Publishing Company, Iowa, USA

Kobayashi H, A Ishida, A Ashihara, K Nakashima, M Katsumata (2012). Effects of dietary low level of threonine and lysine on the accumulation of intramuscular fat in porcine muscle. Biosci Biotechnol Biochem 76:2347-2350

Lerch S, JAA Pires, C Delavaud, KJ Shingfield, D Pomiès, B Martin, A Ferlay (2015). Rapeseed or linseed in dairy cow diets over 2 consecutive lactations: Effects on adipose fatty acid profile and carryover effects on milk fat composition in subsequent early lactation. $J$ Dairy Sci 98:1005-1018

Li K, Y Chen, C Moran, B Fan, S Zhao (2001). Analysis of diversity and genetic relationships between four Chinese indigenous pig breeds and Australian commercial pig breed. Anim Genet 31:322-325

Li XJ, CX Liu, KL Yang, MJ Liu (2017). Study on differentiation of fetal skeletal muscle development characteristics between German and Chinese merino sheep. Grass-feed Livest 4:1-6

Liu Q, MC Lanari, DM Schaefer (1995). A review of dietary vitamin E supplementation for improvement of beef quality. J Anim Sci 73:3131-3140
Luciano G, FJ Monahan, V Vasta, L Biondi, M Lanza, A Priolo (2009). Dietary tannins improve lamb meat color stability. Meat Sci 81:120-125

Ludden PA, MS Kerley (1998). Amino acid and energy interrelationships in growing beef steers: Effects of energy intake and metabolizable lysine supply on growth. J Anim Sci 76:3157-3168

Manni K, M Rinne, A Huuskonen, P Huhtanen (2018). Effects of contrasting concentrate feeding strategies on meat quality of growing and finishing dairy bulls offered grass silage and barley based diets. Meat Sci 143:184-189

Marques RS, LJ Chagas, FN Owens, FAP Santos (2016). Effects of various roughage levels with whole flint corn grain on performance of finishing cattle. J Anim Sci 94:339-348

McKenna DR, PD Mies, BE Baird, KD Pfeiffer, JW Ellebracht, JW Savell (2005). Biochemical and physical factors affecting discoloration characteristics of 19 bovine muscles. Meat Sci 70:665-682

NRC (2000). Nutrient requirements of beef cattle $7^{\text {th }}$ edn. National Academy Press, Washington DC, USA

Nuernberg K, D Dannenberger, G Nuernberg, K Ender, J Voigt, ND Scollan, RI Richardson (2005). Effect of a grass-based and a concentrate feeding system on meat quality characteristics and fatty acid composition of longissimus muscle in different cattle breeds. Livest Prod Sci 94:137-147

O'Connor JD, CJ Sniffen, DG Fox, W Chalupa (1993). A net carbohydrate and protein system for evaluating cattle diets: iv. Predicting amino acid adequacy. J Anim Sci 71:1298-1311

O'Fallon JV, JR Busboom, ML Nelson, CT Gaskins (2007). A direct method for fatty acid methyl ester synthesis: Application to wet meat tissues, oils, and feedstuffs. J Anim Sci 85:1511-1521

Oliveira PPA, RRS Corte, SL Silva, PHM Rodriguez, LS Sakamoto, AF Pedroso, RR Tullio, A Berndt (2018). The effect of grazing system intensification on the growth and meat quality of beef cattle in the Brazilian Atlantic Forest biome. Meat Sci 139:157-161

Perry D, JM Tompson, IH Wang, A Butchers, A Ean (2001). Relationship between objective measurements and taste panel assessment of beef quality. Aust J Exp Agric 41:981-989

Petit HV (2005). Digestion, milk production, milk composition, and blood composition of dairy cows fed whole flaxseed. $J$ Dairy $\mathrm{Sci}$ 85:1482-1490

Priolo A, D Micol, J Agabriel (2001). Effects of grass feeding systems on ruminant meat colour and flavour. A review. Anim Res 50:185-200

Schafer A, K Rosenvold, PP Purslow, HJ Andersen, P Henckel (2002). Physiological and structural events post mortem of importance for drip loss in pork. Meat Sci 61:355-366

Schwaiger T, KA Beauchemin, GB Penner (2013). The duration of time that beef cattle are fed a high-grain diet affects the recovery from a bout of ruminal acidosis: Dry matter intake and ruminal fermentation. J Anim Sci 91:5729-5742

Scollan ND, NJ Choi, E Kurt, AV Fisher, M Enser, JD Wood (2001). Manipulating the fatty acid composition of muscle and adipose tissue in beef cattle. Brit J Nutr 85:115-124

Semba RD, M Shardell, FA Sakr Ashour, R Moaddel, I Trehan, KM Maleta, M Isabel Ordiz, K Kraemer, MA Khadeer, L Ferrucci, MJ Manary (2016). Child stunting is associated with low circulating essential amino acids. Ebiomedicine 6:246-252

Swatland HJ (1997). Internal Fresnel reflectance from meat microstructure in relation to pork paleness and pH. Food Res Intl 30:565-570

Touno E, M Kaneko, S Uozumi, H Kawamoto, S Deguchi (2013). Evaluation of feeding value of forage soybean silage as a substitute for wheat bran in sheep. Anim Sci J 85:46-52

Vieira C, AM Fernández (2014). Effect of ageing time on suckling lamb meat quality resulting from different carcass chilling regimes. Meat $\mathrm{Sc}$ 96:682-687

Wales WJ, JB Moran, RW Harris (1998). A comparison of growth rates and carcass quality of steers receiving maize silage as a supplement to annual pasture or as a component of a feedlot ration. Aust J Exp Agric $38: 1-6$

Wang CL, ZL Hao, FD Li, Y Yu, X Lang, YJ Ma, F Nian, JP Guo (2009). Histomorphometric changes of stomach in grazing Gansu Alpine Finewool Sheep at 0-56 day of age. J Gansu Agric Univ 44:10-15 
Wang T, MJ Hou, ZH Shang, HC Wang (2018). Characteristics of muscle fibers and relative meat quality of fattening sheep fed sweet sorghum silage and corn silage diets. Pratac Sci 35:2722-2727

WHO - World Health Organization (2003). Diet, nutrition and the prevention of chronic diseases: Report of a joint WHO/FAO expert consultation, Vol. 916. World Health Organization, Geneva, Switzerland

Wood JD, RI Richardson, GR Nute, AV Fisher, MM Campo, E Kasapidou, PR Sheard, M Enser (2004). Effects of fatty acids on meat quality: A review. Meat Sci 66:21-32
Yu S, J Derr, TD Etherton, PM Kris-Etherton (1995). Plasma cholesterolpredictive equations demonstrate that stearic acid is neutral and monounsaturated fatty acids are hypocholesterolemic. Amer J Clin Nutr 61:1129-1139

Zeng YQ, YM Sun, H Wang, TS Li (1999). Studies on physicochemical properties and eating quality of grey goat meat. $J$ Shand Agric Univ 30:384-389

Zhao JX, XD Liu, JX Zhang, YW Wang, HQ Li (2015). Effect of different dietary energy on collagen accumulation in skeletal muscle of ram lambs. J Anim Sci 93:4200-4210

Zhao YA, YF Yang (2003). Study on the law of muscle fiber growth of landrace rong chang pigs. Sich Anim Husb Vet 30:22-23 